\title{
A NEW SPECIES OF THE FAMILY ALYCIDAE (ACARI, ENDEOSTIGMATA) FROM SOUTHERN SIBERIA, RUSSIA
}

\author{
Matti Uusitalo \\ Zoological Museum, Center for Biodiversity, University of Turku, Turku, Finland \\ e-mail: matti.uusitalo47@gmail.com
}

ABSTRACT: A new species is described from southern Siberia, Tuva Republic, Russia: Amphialycus (Amphialycus) holarcticus sp.n. (Acari, Endeostigmata, Alycidae). This species can be recognized by its broad naso with longitudinally arranged striae; two pairs of cheliceral setae, posterior one being forked; three pairs of adoral setae; and a large number of genital setae. Two pairs of palpal eupathidia are close to each other, representing a kind of transitional form towards the fusion of the basal parts of eupathidia, observed in the subgenus Orthacarus.

KEY WORDS: Mites, Amphialycus, taxonomy, Asia.

DOI: 10.21684/0132-8077-2020-28-2-109-113

\section{INTRODUCTION}

Mites of the family Alycidae G. Canestrini and Fanzago, 1877 (Acari, Endeostigmata) are freeliving soil-dwellers, characterized by a worldwide distribution. A recent revision of the family by Uusitalo (2010) has focused on the European species. Meanwhile, species from other regions are virtually unknown. For example, alycids were not included in a recent thorough checklist of the mites of Pakistan (Halliday et al. 2018). There are only four records of the tribe Alycini G. Canestrini and Fanzago, 1877 from Asia: Alycus roseus C.L.Koch, 1842 from Tuva, Russia (Uusitalo 2010); Alycus denasutus (Grandjean, 1937) from Iran (Naghibinejad et al. 2009); and Pachygnathus nipponicus Shiba, 1982 and Pachygnathus ornithorhynchus sensu Shiba (1982) from Japan. No records of the tribe Petralycini Uusitalo, 2010 have been reported from Asia. Another alycid tribe, Proteromichaeliini Uusitalo, Ueckermann and Theron, 2020 is African. The tribe Bimichaeliini Womersley, 1944 is more common than the aforementioned ones. For example, Bimichaelia sp. has been recorded from China by Peng et al. (1988). Similarly, in the 1960s and 1970s, within the framework of the International Biological Program (IBP), the following species have been reported and described from Asia by Shiba (1969, 1976): Bimichaelia reticulata Shiba, 1969 and Bimichaelia diadema sensu Shiba (1969) from Japan; Bimichaelia torrida Shiba, 1976 (=Bimichaelia torridus Shiba, 1976, wrong gender), Bimichaelia arbusculosa sensu Shiba (1976), and Laminamichaelia shibai Uusitalo, Ueckermann et Theron, 2020 (=Bimichaelia ramosus Shiba, 1976, nom. preocc.) from the Malay Peninsula. Based only on the original descriptions, they all probably belong to the genus Laminami- chaelia Uusitalo, 2010 and should be re-examined. For example, Bimichaelia ramosus was redescribed and renamed as Laminamichaelia shibai Uusitalo et al., 2020 in a recent review of the South African Alycidae (Uusitalo et al. 2020).

Furthermore, Bimichaelia grandis was described by Berlese (1913) from the island of Java, Indonesia; this species will be redescribed based on recent material from Polynesia. Here, we describe an alycine species, Amphialycus holarcticus sp.n. from Russia, referred to as 'amp' in my revision (Uusitalo 2010).

\section{MATERIALS AND METHODS}

The samples were collected by the author using a collapsible, full-sized Berlese-funnel system (Norton and Kethley 1988). The specimens were examined by SEM (Scanning Electron Microscope, JEOL JSM-5200) after being dehydrated by critical point drying (CPD) and coated with gold.

The character states of clades above the species level are only briefly commented on here. My revision of the family Alycidae (Uusitalo 2010) should be used for descriptions of the family, tribe and genus. This work should also be used as a key to species and synonymy.

We used the standardized terminology proposed for various morphological features of Prostigmata; abbreviations mainly follow Kethley (1990). In species of the family Alycidae, gender cannot be recognized by SEM-micrographs unless the genital valves are open - enough to allow the counting of eugenital setae.

The holotype was collected from the Republic of Tuva, Central Asia; the North American specimens are from the State of Utah. 


\section{SYSTEMATICS} 1877

Family Alycidae G. Canestrini and Fanzago,

The presence of two pairs of prodorsal sensilla (ve and sci) inserted in separate bothridia (=large pores) is the easiest way to recognize these soft, sack-like and segmented species of Alycidae (Fig. 2).

\section{Tribe Alycini G. Canestrini and Fanzago, 1877 Type genus: Alycus C.L. Koch, 1842}

The tribe Alycini can be separated from the tribes Proteromichaeliini, Bimichaeliini and Petralycini, as well as from the rest of the Endeostigmata, by the presence of rudimentary posterior pair of lateral eyes, two pairs of filamentous sensilla and chelate chelicerae with two to four teeth each (Figs. 1 and 4).

\section{Amphialycus Zachvatkin, 1949}

Type species: Amphialycus pentophthalmus Zachvatkin, 1949; by original designation.

The genus differs from other genera of the family by a pubescent pair of setae in; elongated and robust chelicera (Fig. 1); microtrichous palpal eupathids (Fig. 4), which may be separated (subgenus Amphialycus) or basally fused (subgenus Orthacarus); and by empodia densely setulated.

\section{Amphialycus (Amphialycus) holarcticus sp. $n$.}

Figs. 1-10

Description: Dorsum (Figs. 1, 2). Length 560-700 $\mu \mathrm{m}$; ciliate setae with longer central points in caudal segments; naso prominent, cone-shaped, longitudinally striated, pilose setae $v i$, sce and exp on hard integument, exp smallest, setae in pubescent, two pairs of filamentous sensilla ve and sci ciliated entire length, anterior pair of lateral eyes glabrous.

Venter (Figs. 5, 6). Setae numerous and short; genital setae 35-45 per valve; anal setae 5-9 per valve.

Gnathosoma (Figs. 1, 3, 4). Two pairs of cheliceral setae, smooth anterior pair abaxially, forked posterior pair in more dorsal position; rutella widen to a round hyaline membrane with two lobes apically, three pairs of well-developed adoral setae; four microtrichous eupathidia on palps close to each other but clearly apart.

Legs (Figs. 6-9). Setae elongated; solenidial formula for tarsi, tibiae, genua and femora on legs
I-II-III-IV, respectively: $2-1-0-0,3-2-2-0$, $3-2-2-1,2-0-0-1+0$, spine-like famulus on tarsus I and II.

Type material. Holotype from a Larix stand, $100 \mathrm{~m}$ away from the river, on northern slope, litter and soil under Larix, Rhododendron, Spiraea, Clematis, Caragana and Pleurozium, Tuva Republic, Russia, southern range of Tannu-Ola, 1,350 m a. s. $1 ., 50^{\circ} 54^{\prime} \mathrm{N}, 9^{\circ} 29^{\prime} \mathrm{E}$, Aryskanny-Khem River, $5 \mathrm{~km}$ ENE of the Khol-Oozha Village, 18 July 1995, sample MU 95-39, Matti Uusitalo; USA, Utah, Blacksmith Fork Canyon, ex Utah juniper duff, 24 April 1970, G.F.Knowlton and W.J.Hanson: 15 ex., Acarology Laboratory, Ohio State University, OSU coll. no. AL0726 sub Alycus sp.

Type depository. Holotype on SEM-stub U200 at Zoological Museum, University of Turku, Finland (ZMT); one paratype female at Zoological Museum, University of Turku; 9 paratype females and 4 paratype males at Acarology Laboratory, Ohio State University.

Etymology. The specific name refers to the circumpolar distribution of the species.

Differential diagnosis. This species can be distinguished from the other Amphialycus species by the following: its broad naso with longitudinally arranged striae (Fig. 1) (vs. striae arranged transversely or naso being a roundish button or absent (Uusitalo 2010: figs. 4, 71, 82; Uusitalo et al. 2020: figs. 30, 49, 64)); two pairs of cheliceral setae, with the posterior one being forked (Figs. 1, 3) (vs. one pair of smooth cheliceral setae abaxially or cheliceral setae absent (Uusitalo 2010: figs. 4, 5, 74; Uusitalo et al. 2020: figs. 34, 48, 68)); three pairs of adoral setae (Fig. 4) (vs. one or two pairs (Uusitalo 2010: figs. 70, 79; Uusitalo et al. 2020: figs. 36, 52, 69)); and 35-45 genital setae per valve (Fig. 5) (vs. 21-24 genital setae in A. leucogaster, 12-18 genital setae in A. oblongus, 21-22 in A. acacia, 19-22 in A. adustus, 17-24 in A. mayteni (Uusitalo et al. 2020: figs. 32, 51, 72, 79)). Two pairs of palpal eupathidia are close to each other (Figs. 3, 4) - a kind of transitional form towards the fusion of the basal parts of eupathidia, observed in the subgenus Orthacarus (Uusitalo 2010: fig. 85).

\section{DISCUSSION}

Mites of the family Alycidae are not of economic importance - they are not pests or useful in controlling pests or weeds - and therefore not subjects of any intensive investigation in that sense. People's fascination with this family is a result of the prehis- 

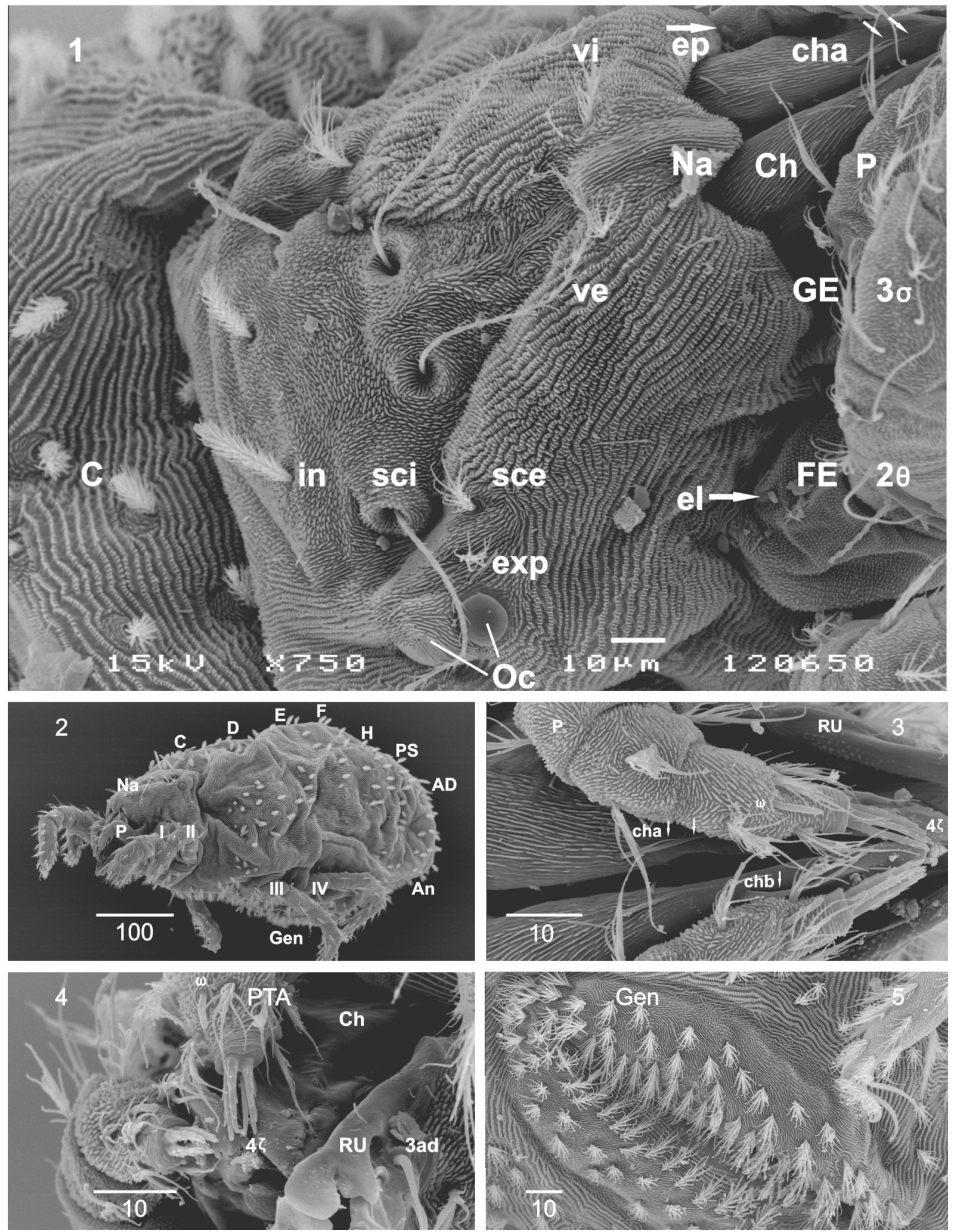

Figs. 1-5. Amphialycus holarcticus sp.n. 1-Prodorsum with conical naso, setae vi, sce and exp on hard integument, plus forked cheliceral cha (two small arrows), supracoxal setae of palp and leg I (large arrows), Genu I (3 solenidia), Femur I (2 solenidia); 2-Lateral habitus, integument with continuous ridges; 3-Two pairs of cheliceral setae, chb simple (one arrow) cha forked (two arrows); 4-Four microtrichous eupathids on palps, rutellum lobed, 3 pairs of adoral setae; 5-Genital valves with 42-44 setae. 

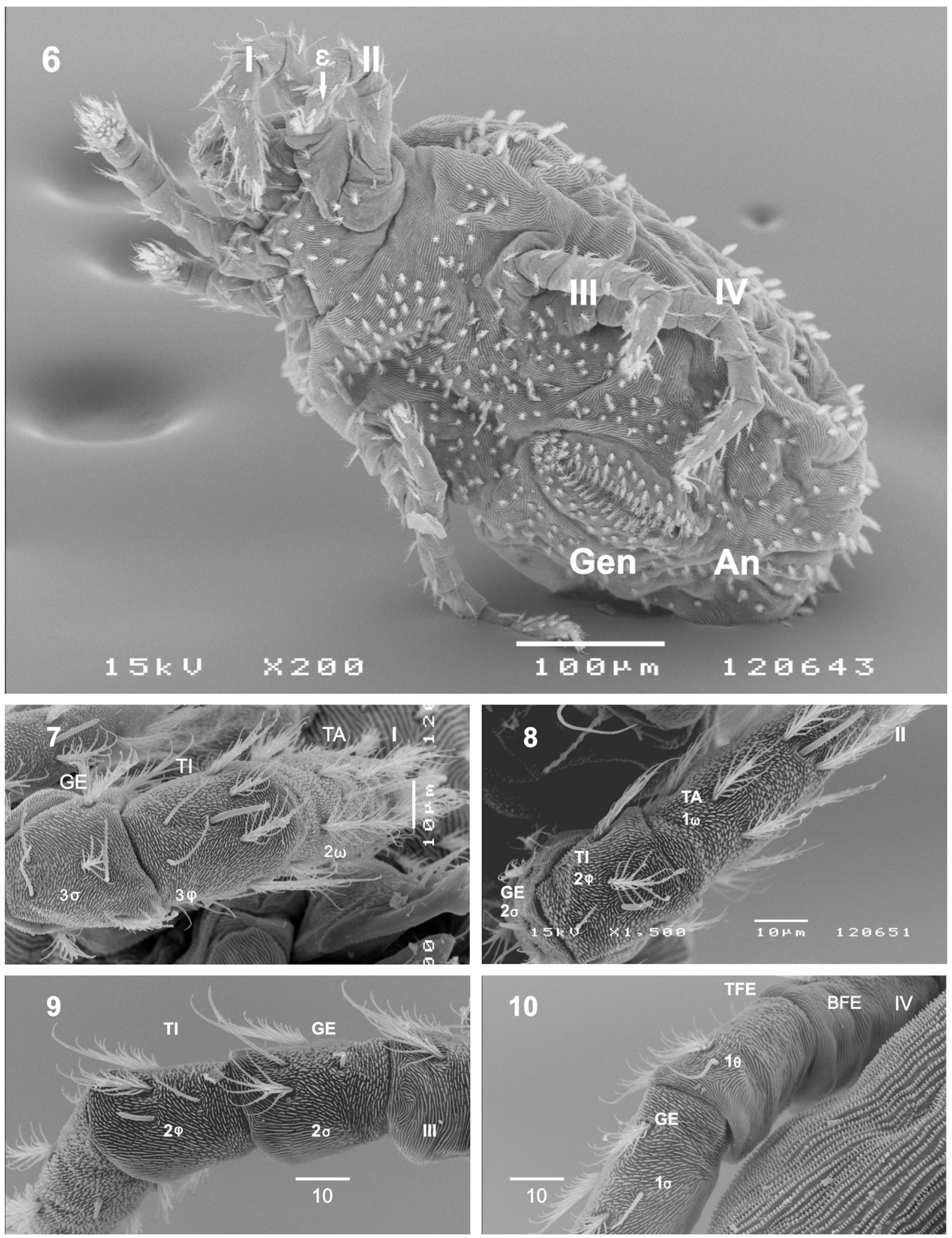

Figs. 6-10. Amphialycus holarcticus sp.n. 6-Ventral habitus with prominent neotrichy, genital valves with 42-44 setae, anal valves with seven setae, famulus II (arrow); 7-Tarsus I ( 2 solenidia), Tibia I ( 3 solenidia), Genu I (3 solenidia); 8-Tarsus II (1 solenidion), Tibia II (2 solenidia), Genu II (2 solenidia); 9-Tibia III (2 solenidia), Genu III (2 solenidia); 10 - Genu IV (1 solenidion), Telofemur IV (1 solenidion). 1-10 from Russia (SEM-stub U200). 
toric nature of the phenotypical characteristics of its members. Plesiomorphic character states, e.g., soft, sack-like and segmented body, two pairs of bothridial sensilla, chelate-dentate chelicera, linear palps and four pairs of walking legs strongly support the idea of an ancient origin of the family, although strong fossil evidence is still missing (Sidorchuk 2018).

The intense early descriptive work was inadequate to allow species identification. Kethley (1982) stated that the family contains 7 nominal genera and 34 nominal species, but only 4 of the genera and 11 of the species were recognizable. Based on the global material, phylogenetic analysis revealed 2 subfamilies, 4 tribes, 6 genera, and, to date, about 50 species of alycid mites. However, only 30 of the species are accurately described (Uusitalo 2010, Uusitalo et al. 2020). This paper is an effort to advance our knowledge of alycid biodiversity.

\section{ACKNOWLEDGEMENTS}

I thank the following people for their general help and technical assistance: Dr. Pekka T. Lehtinen (Senior Curator of ZMT), the late Dr. Michael Saaristo, Mrs. Ritva Penttinen (MSc), Mr. Veikko Rinne (MSc), Mr. Seppo Koponen (PhL) and Mr. Ari Karhilahti from the University of Turku. The grant of the Finnish Academy of Sciences made my expedition to Siberia in 1995 possible. I also thank Dr. Sergei Mironov (Zoological Institute RAS, Russia) and two anonymous reviewers, who have provided helpful suggestions.

\section{REFERENCES}

Berlese, A. 1913. Acari nuovi. Manipoli VII-VIII. Redia, 9: 77-111.

Halliday, B., Kamran, M. and Bashir, M.H. 2018. Checklist of the mites of Pakistan. Zootaxa, 4464(1): $1-178$.

Kethley, J.B. 1982. Acariformes. Prostigmata. In: S.P. Parker (Ed.). Synopsis and Classification of Living Organisms Vol. 2. McGraw-Hill, New York, pp. 117-145.
Kethley, J.B. 1990. Acarina: Prostigmata (Actinedida). In: L.D. Dindal (Ed.). Soil Biology Guide. John Wiley and Sons, New York, pp. 667-756.

Naghibinejad, M., Ahadiyat, A., Ostovan, H. and Moradiyan, H. 2009. First report of a genus and species of the Family Alycidae (Acari: Endeostigmata) from Iran. Plant Protection Journal, 1(3): 337-339.

Norton, R.A. and Kethley, J.B. 1988. A collapsible, full-sized Berlese-funnel system. Entomological News, 99: 41-47.

Peng, C., Zaigen, W., Aoki, J., Shiba, M. and Ishikawa, K. 1988. Investigation on soil Acarid in Jingyuetan area Changchun. Acta Zoologica Sinica, 34: 282-292.

Shiba, M. 1969. Taxonomic Investigations on Freeliving Mites in the Subalpine Forest on Shiga Heights IBP Area. Prostigmata. Bulletin of $\mathrm{Na}$ tional Science Museum, Tokyo, 12: 65-115.

Shiba, M. 1976. Taxonomic investigation on free-living Prostigmata from the Malay Peninsula. Nature and Life in SE Asia, Kyoto, 7: 83-229.

Shiba, M. 1982. The mites of the genus Pachygnathus Duges (Acarina: Actinedida) from Japan. Reports of Research, Matsuyama Shinonome Junior College, 13: 55-66.

Sidorchuk, E.A. 2018. Mites as fossils: forever small? International Journal of Acarology, 44 (8): 349-359.

Uusitalo, M. 2010. Revision of family Alycidae (Acariformes, Acari), with special reference to European species. $\mathrm{PhD}$ thesis. University of Helsinki, Helsinki University Print, $143 \mathrm{pp}$. Date of access: 20.08.2020. http://ethesis.helsinki.fi

Uusitalo, M., Ueckermann, E.A. and Theron, P.D. 2020. A review of the family Alycidae (Acari, Acariformes) from South Africa. Zootaxa, 4858(3): 301-340.

Zachvatkin, A.A. 1949. Novie predstaviteli segmentirovannykh kleshchey (Acarina, Pachygnathidae) [New representatives of segmented mites (Acarina, Pachygnathidae)]. Entomologicheskoe Obozrenie, 30: 292-297. [In Russian] 